\title{
EFFECTS OF PREDICTABLE TAX LIABILITY VARIATION ON HOUSEHOLD LABOR INCOME
}

\author{
Naomi E. Feldman \\ Peter Katuščák
}
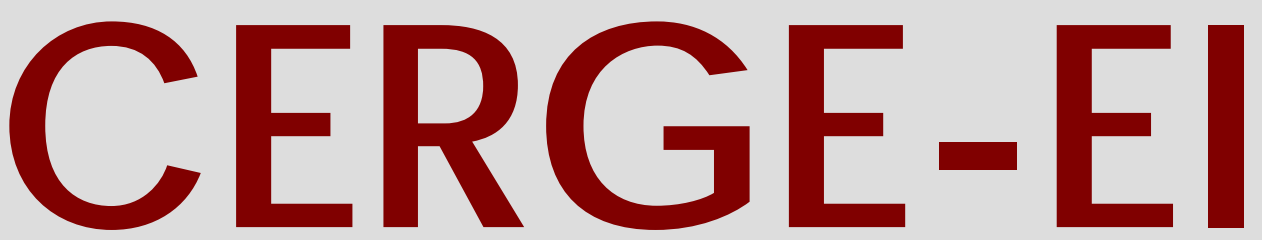

Cha rles University Centerfor Ec onomic Research and Graduate Education Academy of Sciences of the Czech Republic Ec onomic s Institute 


\section{Working Paper Series 454 (ISSN 1211-3298)}

\section{Effects of Predictable Tax Liability Variation on Household Labor Income}

Naomi E. Feldman

Peter Katuščák

CERGE-EI

Prague, February 2012 
ISBN 978-80-7343-257-7 (Univerzita Karlova. Centrum pro ekonomický výzkum a doktorské studium)

ISBN 978-80-7344-249-1 (Národohospodářský ústav AV ČR, v.v.i.) 


\title{
Effects of Predictable Tax Liability Variation on
}

\author{
Household Labor Income*
}

\author{
Naomi E. Feldman ${ }^{\dagger}$ and Peter Katuščák ${ }^{\ddagger}$
}

February 2012

\begin{abstract}
Economic theory assumes that taxpayers use their true marginal tax rate (MTR) to guide their economic decisions. However, due to complexity of the tax system, taxpayers may incorrectly perceive their MTR, with implications for incentives. We first develop an updating model that formalizes this conjecture. It predicts that an unexpected increase in the previous year's tax liability pushes up the perception of the MTR in the current year, even though the MTR does not, in fact, change. We then examine whether household labor income responds to predictable (but not necessarily predicted) lump-sum variation in the previous year's tax liability due to loss of eligibility for the Child Tax Credit when the eligible child turns 17. Using an identification strategy based on an eligibility discontinuity, we find that losing the credit reduces, ceteris paribus, parental labor income in the year following the loss of the credit. This result is robust to a variety of tests and different data sources. Because it cannot be explained by an income effect or credit constraints, such a finding is inconsistent with the taxpayers being fully rational and fully informed. We interpret it as being driven by a substitution effect on labor supply due to imperfect ex-post understanding of the change in the tax schedule.
\end{abstract}

Keywords: tax salience, tax complexity, labor income

JEL Classification: H21, H24, H31

*We would like to thank Kate Antonovics, Eli Berman, Mike Christian, Julie Cullen, John Diamond, Libor Dušek, Roger Gordon, Štěpán Jurajda, Jeff Liebman, Marco Manacorda, Karen Pence, Dan Shaviro, Joel Slemrod, seminar participants at UCSD, Hebrew University, CERGE-EI, CEU, Pompeu Fabra, Collegio Carlo Alberto, University of Copenhagen and Norwegian School of Economics and Business Administration and numerous conference participants for helpful comments and suggestions. We also thank Petr Chovanec and Marek Rusnák for excellent research assistance. Financial support from the Grant Agency of the Czech Republic (402/10/2085) and Global Development Network (RRC IX-04) is gratefully acknowledged. Any remaining errors are our own.

${ }^{\dagger}$ Research Division, Federal Reserve Board, Washington, D.C. 20551, USA, naomi.e.feldman@frb.gov.

${ }^{\ddagger}$ CERGE-EI, P.O.Box 882, Politických vězňů 7, 11121 Praha 1, Czech Republic, Peter.Katuscak@cergeei.cz. CERGE-EI is a joint workplace of the Center for Economic Research and Graduate Education, Charles University, and the Economics Institute of Academy of Sciences of the Czech Republic. 


\begin{abstract}
Abstrakt
Ekonomická teorie předpokládá, že daňoví poplatníci používají jejich skutečnou marginální daňovou sazbu (MDS) pro své ekonomické rozhodování. Avšak vzhledem k složitosti daňového systému mohou daňoví poplatníci jejich MDS vnímat nesprávně, což ovlinňuje jejich motivaci. V tomto článku nejprve vytváříme model aktualizace poznatků, který formalizuje tento dohad. Model předpovídá, že neočekávané zvýšení daňové povinnosti v předcházejícím roce tlačí nahoru vnímání MDS v běžném roce, a to i přesto, že MDS se ve skutečnosti nemění. Následně provádíme empirické zkoumání, zda pracovní př́immy domácností reagují na předvídatelné (ale ne nezbytně předvídané) paušální změny $\mathrm{v}$ dani z příjmů v předchozím roce spůsobené ztrátou práva na daňový bonus pro nezletilé dítě, když toto dítě dovrší věk 17 let. Použitím identifikační strategie založené na věkové diskontinuitě zjišťujeme, že ztráta bonusu snižuje, ceteris paribus, rodičovské pracovní př́ímy v roce následujícím po ztrátě bonusu. Tento výsledek je robustní na řadu testů a různých datových zdrojů. Vzhledem k tomu, že není možné tento výsledek vysvětlit účinkem příjmu nebo kreditních omezení, je v rozporu s plnou racionalitou a informovaností daňových poplatníků. Interpretujeme tento výsledek jako substituční efekt na nabídku práce v důsledku nedokonalého ex-post porozumění změny v daňové křivce.
\end{abstract}




\section{Introduction}

Economic theory presumes that individuals respond to marginal prices when deciding on their labor supply, portfolio allocation, saving decisions, and many other behavioral margins. Because marginal prices are affected by marginal tax rates (MTRs), the latter have been recognized as important for behavioral responses. Indeed, there is now a voluminous empirical literature identifying significant behavioral responses to tax changes. ${ }^{1}$

Under the usual interpretation, these responses are attributed to changes in MTRs. This interpretation assumes, however, that taxpayers correctly perceive their MTRs and, as a result, marginal net-of-tax prices. The existing empirical evidence on such assumption is mixed, however. ${ }^{2}$ One plausible reason why households may not have perfect information about their tax-induced incentives is due to complexity of the income tax. Indeed, the U.S. federal income tax code is filled with various deductions, credits, and exemptions, and knowing when one is or is not eligible for them requires a detailed knowledge of diverse and often arbitrary eligibility rules, phase-in and phase-out ranges, and possibly other details. For example, in their 2005 report, the President's Advisory Panel on Federal Tax Reform ${ }^{3}$ laments:

"There is no clearer proof of the complexity of the tax code than the collective anxiety felt by Americans every April as the tax filing deadline approaches. For many, filing taxes consists first of procrastination. Then there is the inevitable search for slips of paper containing once-meaningful but now unintelligible financial transactions. Then comes the maze of lengthy instructions complex enough that even highly schooled professionals have to reread the directions several times. Those directions send taxpayers on a search through

\footnotetext{
${ }^{1}$ See, for example, Eissa (1995) or Eissa and Liebman (1996) for labor force participation of women, Looney and Singhal (2006) for the intertemporal elasticity of labor earnings, Goolsbee (2000) for the timing of income realization, Poterba and Samwick (2003) for risk-taking and portfolio behavior, and Feldstein (1995), Auten and Carroll (1999), Gruber and Saez (2002), and Kopczuk (2005) for reported and taxable income. On the other hand, Saez (2004) finds that only the top 1\% of incomes show evidence of behavioral responses to taxation.

${ }^{2}$ See Section 2.

${ }^{3}$ In "Simple, Fair, and Pro-Growth: Proposals to Fix America's Tax System", a report of the President's Advisory Panel on Federal Tax Reform, November 2005. Source: www.taxreformpanel.gov.
} 
baffling schedules and detailed worksheets requiring many illogical and counterintuitive computations. And in the end, most taxpayers give up, and visit a tax preparer who promises to make sense of the whole process - for a price."

"To determine something as basic as figuring out the tax implications of having a child, you need to review numerous rules and complete many separate sets of computations. Figuring out whether you can claim the child tax credit, for example, requires the skills of a professional sleuth: You need to complete eight lines on a tax form, perform up to five calculations, and fill out as many as three other forms or schedules. Further research, reading, and computation may be needed to determine whether you can claim head of household filing status, an exemption for a dependent, the child and dependent care credit, the earned income tax credit, or tax credits related to your child's education, to name only some of the possibilities."

Similar warnings appear in academic work as well. For example, Kotlikoff and Rapson (2007) argue that "thanks to the incredible complexity of the U.S. fiscal system, it's impossible for anyone to understand her incentive to work, save, or contribute to retirement accounts absent highly advanced computer technology and software." However, experts are not the only ones who complain. According to a 2003 NPR/Kaiser Family Foundation/Kennedy School of Government Taxes Survey, 36 percent of respondents are more bothered by complexity of the federal income tax system than by the amount they pay in taxes or the feeling that rich people do not pay their "fair" share. ${ }^{4}$ In addition, 90 percent of the respondents find the tax system very or at least somewhat complicated. ${ }^{5}$ When asked what factors contribute to this complexity, the respondents named factors such as "too much record-keeping" (62 percent), "too many different tax rates" (59 percent), or "forms being too hard to fill" (56 percent). However, all of these percentages are overwhelmed

\footnotetext{
${ }^{4}$ This finding is based on the following question: "Which of the following bothers you most about taxes: the large amount you pay in taxes, the complexity of the tax system, or the feeling that some wealthy people get away not paying their fair share?"

${ }^{5}$ This finding is based on the following question: "How complex do you think the current federal income tax system is? Do you think it is very complex, somewhat complex, not too complex or not complex at all?"
} 
by 96 percent of the respondents thinking that complexity is partially due to "so many different kinds of deductions and tax credits, and so many rules about how to take them." Moreover, 64 percent consider the latter to be the most important source of complexity.

Figure 1 gives a taste of this complexity. It plots the effective and statutory federal MTR excluding payroll taxes for married couples filing jointly in 2002 as a function of household labor income, assuming no other income. It deliberately focuses on the income range up to $\$ 40,000$, in which the actual effective MTR is highly non-monotone and quite variable. This is in contrast to the statutory tax schedule under which the MTR is an increasing step function of income with few brackets. In addition, both the effective and the statutory MTR schedules vary with the number of dependents claiming the personal exemption. On top of that, fixing the number of dependents, the effective MTR schedule, but not the statutory one, also varies with the number of dependents eligible for the Child Tax Credit.

In response to this complexity, taxpayers are increasingly looking to experts or computer software for help. ${ }^{6}$ To the extent that a preparer or software is used only as a tax compliance tool or an ex post minimizer of tax liability, it is not clear that the use of these tools leads to better informed taxpayers. On the contrary, tax preparers and software allow taxpayers to escape the complexity of the tax code to a large degree, which is likely to further reduce taxpayer knowledge of the tax system. Put differently, by going through their tax forms and instructions the old-fashioned way, line by line, taxpayers who use the traditional method of tax filing may actually be better informed about details of the tax system.

There are two fundamental reasons why such complexity may result in taxpayers having imperfect knowledge about the tax system with which they interact. First, complexity makes it costly for taxpayers in terms of cognitive abilities, time, or money to learn about the details. It is therefore plausible that many taxpayers are not aware of some or most tax

\footnotetext{
${ }^{6}$ For example, of about 130 million of individual tax returns filed for the tax year 2001, 72.5 million, or 56 percent, were prepared by a professional preparer. More recently, this fraction has been approaching two thirds. Many taxpayers are also turning to tax preparation software, which, beyond simplification, also offers the benefits of electronic filing (if chosen) and a faster refund. For example, about 47 million, or 36 percent, of returns were e-filed in 2001. By 2006, this number had jumped to 80 million, or 58 percent. Source: Statistics of Income Division of the Internal Revenue Service.
} 
law provisions that currently affect them, or that will affect them in the future. Note that this argument does not rely on bounded rationality. It simply stresses the fact that gathering and processing information is costly, so even fully rational economic agents may prefer to have less than perfect knowledge of the tax schedule. They then use any information they get from the interaction with the tax system, as well as any related signals, to update their beliefs. Following Feige and Pearce (1976) and Buiter (1980), this is referred to as economically, as opposed to technically, optimal belief formation. Second, taxpayers may be boundedly rational. In this case, a certain framing of tax changes makes them more salient, resulting in taxpayers being more responsive, and vice versa.

There are two degrees to which taxpayers may have misperceptions about the tax system they interact with. First, they may experience ex ante misperceptions. This is the case when taxpayers fail to predict a future change in the tax schedule that will impact them even though the change is predictable. For example, at the cross-sectional level, a household loses eligibility for the Child Tax Credit when their child turns 17. Alternatively, at the aggregate level, some tax cuts come with sunset provisions, such as the Economic Growth and Tax Relief Reconciliation Act of 2001. Such changes in the tax schedule are predictable, but may not necessarily be predicted by taxpayers ex ante. When experiencing ex ante misperceptions, households may fail to intertemporarily optimize their behavior and they may exhibit "excess behavioral sensitivity" to predictable changes in the tax schedule. This argument is closely related to empirical research on the permanent income hypothesis (PIH), especially the finding that consumption tends to increase after predictable income increases despite an absence of credit constraints. ${ }^{7}$

Second, taxpayers may experience ex post misperceptions. This is the case when taxpayers misperceive or misinterpret a change in the tax schedule which they have already experienced. For example, suppose that a household receives an unexpected tax rebate check from the government or it realizes an unexpected increase in its after-tax income. With imperfect understanding of the source of the surprise, the household may interpret it in multiple ways. First, the after-tax income increase could reflect a lump-sum tax de-

\footnotetext{
${ }^{7}$ We discuss this point in more detail in Section 7.
} 
crease, as would be the case if a household gains an eligible child for the Child Tax Credit, or a tax cut, as would be the case following the 2001 tax rebate, for example. ${ }^{8}$ Second, the surprise could reflect a tax decrease or a tax cut derived from an across the board decrease in the MTR, as would be the case following the Tax Reform Act of 1986, for example. Third, it could simply be a timing shift in the receipt of after-tax income, as would be the case following the 1991-92 reduction in income tax withholding, for example. As long as the household has imperfect prior information about both the level and the slope of the tax schedule, the unexpectedly high after-tax income will, in general, be partly interpreted in all three ways. Naturally, other interpretations are possible as well.

The first contribution of this paper is in developing a model that formalizes this intuition. The model generalizes the standard full-information rational agent model by allowing for imperfect knowledge of the income tax schedule. In the model, a household is subject to a linear income tax schedule that changes from year to year due to innovations that are predictable, but not necessarily predicted, well in advance. ${ }^{9}$ The household perceives these innovations with noise due to information gathering and processing costs. As a result, the household is uncertain about the exact tax schedule it faces and it will use any signals generated by its interaction with the tax system to update its beliefs. In particular, the model illustrates that beliefs about current and future MTRs may increase (decrease) with a surprisingly high (low) tax liability realized in the previous tax year.

The second contribution of the paper is in devising and implementing an empirical strategy that can identify whether households have perfect understanding of their tax schedule changes (null hypothesis) or whether they experience (ex ante or ex post) misperceptions, particularly of their MTR (alternative hypothesis). We identify a variation across households in the change of tax liability from one year to another that is lump-sum, predictable in advance, and exogenous, and examine how this variation affects parental labor income

\footnotetext{
${ }^{8}$ The 2001 tax rebate originated from a 5 percentage point tax cut on the first $\$ 12,000(\$ 6,000)$ dollars of taxable income when filing as a married couple (single). Since this reduction in the MTR was inframarginal for the vast majority of households, the resulting tax cut in the given bracket was, in fact, lump-sum. In addition, many taxpayers experienced effective MTR cuts as well.

${ }^{9}$ Unpredictable tax schedule changes can be incorporated into the model, increasing its complexity but without modifying its predictions.
} 
in married-couple households in the year following the realization of the tax change. ${ }^{10}$ This variation originates from an age-discontinuity in eligibility for the Child Tax Credit (CTC) at the age of 17 . We identify the effect by comparing the growth rate between years $t$ and $t+1$ of the parental labor income of married couples whose child turns 17 before the end of year $t$ and who, therefore, lose the credit in year $t$, to their counterparts whose child turns 17 early in year $t+1$ and who, therefore, do not lose the credit in year $t$. It is important for the variation to be lump-sum and predictable since, in the case there are no ex ante or ex post misperceptions, there should be no reaction by labor income, except perhaps in the presence of liquidity constraints. If only an ex ante misperception is present, a resulting income effect or a liquidity constraint may increase labor income. However, if an ex post misperception is present as well, labor income may decrease, due to the substitution effect.

We implement the identification strategy using panel data from the 1996-1999 and 2000-2003 waves of the U.S. Census Bureau's Survey of Income and Program Participation (SIPP). We find that losing an eligible dependent has a negative impact on the growth rate of parental labor income in the year following the tax year in which the credit was lost. We also replicate the identification strategy on the 2005-2007 repeated cross-sections from the U.S. Census Bureau's American Community Survey (ACS). Using this data, we find the same negative effect on the level of parental labor income in the year following the tax year in which the credit was lost. We show, using a variety of robustness tests, that these findings are not driven by a direct effect of child aging or a spurious correlation between timing of birth and income level or its growth rate.

In light of the previous discussion, these results imply the presence of an ex post misperception. We interpret this finding as suggestive of the fact that households increase their estimate of the MTR and respond via the substitution effect.

The rest of the paper is organized as follows. Section 2 reviews existing empirical evidence on taxpayer confusion, tax complexity, and tax salience. Section 3 presents a model that formalizes the intuition behind ex post misperceptions of tax schedule changes.

\footnotetext{
${ }^{10}$ We focus on labor earnings because this measure captures not only hours worked, but other types of effort (such as looking for a better job) that increase the value of one's labor input.
} 
Section 4 describes our identification strategy. Section 5 describes the datasets that we use and the estimating equations. Section 6 discusses our results and presents a number of robustness checks. Section 7 relates our findings to the empirical literature on the PIH. Finally, Section 8 concludes.

\section{Existing Empirical Evidence on Taxpayer Confu- sion, Tax Complexity, and Tax Salience}

There is a stream of literature in public finance that analyzes how well-informed taxpayers are about the tax system that they face. One strand of this literature focuses on documenting taxpayer perceptions of the income tax schedule. Brown (1968) compares self-reported MTRs of a group of UK taxpayers to their actual MTRs computed from employer pay records and concludes that taxpayers "think they pay higher rates of tax than is in fact the case." Fujii and Hawley (1988), using the Survey of Consumer Finances, compare respondent self-reported MTRs to estimates of these MTRs based on the available survey demographic and income data. They find that individuals systematically underestimate their computed MTRs. ${ }^{11}$ Romich and Weisner (2000) find that a high percentage of lowincome households do not correctly perceive their MTRs implied by the Earned Income Tax Credit (EITC) for hypothetical levels of income. In particular, the respondents' knowledge appears to be based on experience within their current income range, which they incorrectly extrapolate to other income ranges. ${ }^{12}$

Building on the idea of complexity, Liebman and Zeckhauser (2004) propose a simple hypothesis for how households interpret tax liability, or, equivalently, net income shocks. They suggest that households "schmedule", that is, approximate their true MTR by the average tax rate realized in the previous year, and they provide some supportive evidence for this claim. They do not conceptually distinguish between predictable and unpredictable

\footnotetext{
${ }^{11}$ This interpretation is, however, sensitive to the assumption regarding the use of itemized deductions.

${ }^{12}$ For example, households in the phase-in portion of the EITC often assume that the amount of the credit increases linearly with the amount of labor income, even though the amount of the credit flattens out after a certain income threshold, and after another threshold it decreases.
} 
income innovations, however. In fact, we will show in the next section that their hypothesis is a special case of a more general updating model.

Rather than focusing on misperceptions and complexity, another strand of the literature focuses on the hypothesis that certain taxes, or certain ways of framing them, may be more visible, or salient, in comparison with other taxes or other ways of framing them. For example, de Bartolome (1995) provides experimental evidence based on revealed choices that when the tax schedule is presented as a table mapping taxable income to the amount of tax entry by entry (as in the table accompanying the personal income tax form 1040), "there are at least as many individuals who use the average tax rate 'as if' it were the marginal tax rate, as individuals who use the true marginal tax rate." ${ }^{13}$ Blumkin et al. (2012) provide experimental evidence that an income tax induces a greater reduction in labor supply than does a theoretically equivalent consumption tax. They attribute this finding to the fact that direct taxes on income are more salient than indirect taxes on consumption. Chetty et al. (2009), using both a field experiment and an observational study, find that consumer demand depends on whether a consumption tax is included in the posted price of a good despite the fact that the final after-tax price is the same in either case. $^{14}$

\section{Model}

In this section, we formalize the intuitive hypothesis presented in Section 1 about how households interpret net income, or, equivalently, realized tax liability surprises. Formally, suppose that a household faces a linear tax schedule in every period $t \in\{0, \ldots, T\}$ of its lifetime with the MTR given by $\tau_{t}$ and the intercept given by $D_{t}$. That is, the tax liability $T_{t}(y)$ of this household in period $t$ based on taxable income $y$ is determined by

\footnotetext{
${ }^{13}$ However, given that as many as 85 percent of taxpayers nowadays rely either on a tax preparer or tax preparation software, the significance of tax schedule framing for taxpayer decisions potentially affects only a relatively small and declining portion of taxpayers.

${ }^{14}$ Similar results have been obtained experimentally for private goods and services markets. For example, Hossain and Morgan (2006) find that a seller can raise a higher revenue in eBay auctions by cutting the reserve price and increasing the (less salient) shipping cost by the same amount. Choi et al. (2008) find that subjects pick higher fee index funds when allocating fictional investment despite the funds being based on the same index if the fee information is obfuscated by descriptions of past manager performances.
} 
$T_{t}(y)=D_{t}+\tau_{t} y$ for all $y \geq 0$. Since real-world tax schedules are predominantly only piecewise linear, the proposed linear schedule can be thought of as a local approximation of an otherwise more complicated tax scheme in a relevant range. This schedule varies from household to household because of different demographic characteristics such as the number of children and their ages, taxpayers' ages, disability status, type of income, etc. It also varies from year to year due to switches among different linear segments of a more realistic schedule as well as predictable and unpredictable changes in the tax schedule. The predictable changes are due to a variety of provisions related to the ages of the taxpayers or their children, or due to tax consequences of planned actions such as mortgage interest payments. These changes are, under a stable tax system, predictable many years in advance. Unpredictable changes, on the other hand, are due to tax reforms as well as realizations of states of the world that have tax consequences, such as medical expenditures, disabilities, number and timing of children, etc. In the following, we will only focus on predictable changes. Unpredictable changes are obviously realistic, and they can easily be incorporated into the analysis without qualitatively affecting the results.

Formally, the parameters of the tax schedule affecting the household follow a process

$$
\left(\begin{array}{c}
\tau_{t+1} \\
D_{t+1}
\end{array}\right)=\left(\begin{array}{c}
\tau_{t} \\
D_{t}
\end{array}\right)+\left(\begin{array}{c}
\phi_{\tau t+1} \\
\phi_{D t+1}
\end{array}\right)
$$

where $\phi_{t+1} \equiv\left(\phi_{\tau t+1}, \phi_{D t+1}\right)^{T}$ is a vector of predictable changes in the parameters of the tax schedule between years $t$ and $t+1$. However, the household may perceive these changes with an error, resulting in its expectation of the change $\phi_{t+1}^{e}$ diverging from the actual change $\phi_{t+1}$. In particular, from the point of the view of the household, $\phi_{t+1}^{e}-\phi_{t+1}$ is a realization of $N\left(0, S_{t}\right)$. Realizations of $\phi_{t+1}^{e}-\phi_{t+1}$ in different time periods assumed to be independent. Although this simplifying assumption rules out the possibility that a tax liability surprise is perceived as a pure shift in the timing of taxes, it simplifies the exposition and allows us to focus on the confusion between changes in the intercept and the slope of the tax schedule. The matrix $S_{t}$ measures the household's ability to correctly 
perceive the predictable changes. For a perfectly informed household, $S_{t}=0_{2 \times 2}$, and hence the predictable changes are in fact predicted without error. For a less than perfectly informed household, $S_{t}$ is a non-zero positive semi-definite matrix, meaning that $\phi_{t+1}^{e}$ is only a crude measure of the predictable change in the parameters of the tax schedule between periods $t$ and $t+1$. Although the normal distribution places a positive measure on the perceived MTR exceeding unity or falling below any arbitrary negative threshold, the stochastic specification in (1) may be thought of as a tractable approximation of beliefs over a bounded interval and we therefore overlook the problem of unboundedness in the following analysis. ${ }^{15}$

We also assume that the household does not necessarily have exact knowledge of the tax schedule when it first enters the labor force. In particular, its prior beliefs about the MTR and intercept of the tax schedule at the end of period 0 are given by

$$
\left(\begin{array}{c}
\tau_{0} \\
D_{0}
\end{array}\right) \sim N\left[\mu_{0}, \Sigma_{0}\right]
$$

where $\mu_{0}$ is the vector of the actual parameters facing the household. Again, the matrix $\Sigma_{0}$ determines the extent to which the household is aware of the details of the tax schedule when it first enters the labor force. For a fully informed household, $\Sigma_{0}=0_{2 \times 2}$, while for a less that fully informed household, $\Sigma_{0}$ is a non-zero positive semi-definite matrix.

A few technical remarks are in place here. We treat $S_{t}$ and $\Sigma_{0}$ as exogenous, but in reality households have control over how detailed their knowledge of the tax schedule and its changes is. This would suggest introducing an explicit cost of information acquisition and modeling the two variance matrices as outcomes of comparing marginal costs and benefits of information (Feige and Pearce, 1976; Buiter, 1980; Reis, 2006; Demery and Duck, 2007). On a different note, although not due to a conscious effort, the "size" of $S_{t}$ may be an unintended consequence of income variation. For example, if household taxable income

\footnotetext{
${ }^{15}$ An alternative modeling strategy would be to assume mean reversion in the parameters of the tax schedule. This was done in a previous version of the paper and is available upon request. The exposition becomes more complicated with no effect on the qualitative results.
} 
fluctuates in a relatively narrow range from one year to another, switches among different segments of the tax schedule are not so frequent and, hence, $S_{t}$ may be "small". On the other hand, $S_{t}$ may be substantially "larger" if the household experiences large year-toyear taxable income variation. More details of taxable income history may matter as well, in that the household may have more precise beliefs and information about segments of the tax schedule that it encountered in the past. Although these extensions are plausible and worth future exploration, the purpose of the current model is to analytically illustrate mechanics of updating based on realized tax liability in simpler terms, and we therefore proceed with exogenous $S_{t}$ and $\Sigma_{0}$. This can be understood as a reduced-form version of a more complete model with conscious as well as accidental information acquisition. Yet another potential modeling extension is to allow $\phi_{s}^{e}$ for $s>t$ to be updated in period $t$ based on the most recent available information. Incorporating this addition would not affect the central message of the model and we therefore omit it for simplicity.

At the end of period $t$, the household files its tax return for that period. ${ }^{16}$ Conditional on pre-tax income $y_{t}$ in period $t$, the household observes its tax liability $T_{t}=D_{t}+\tau_{t} y_{t}$ which serves as a signal for $\left(\tau_{t}, D_{t}\right)$. The following proposition characterizes the evolution of beliefs about the parameters of future tax schedules based on past and current realizations of tax liability.

Proposition 1 Suppose that $S_{t}$ is positive definite in all time periods, or that three of its elements are zero and the remaining diagonal element is positive. Given this, beliefs about the parameters of the tax schedule in period $s \in\{t+1, . ., T\}$ at the end of period $t$ are given by a normal distribution with mean

$$
\begin{aligned}
E_{t}\left[\left(\tau_{s}, D_{s}\right)^{T}\right] & =E_{t}\left[\left(\tau_{t}, D_{t}\right)^{T}\right]+\sum_{u=t+1}^{s} \phi_{u}^{e} \\
& =\mu_{0}+\sum_{u=1}^{t} \Gamma_{u}\left[T_{u}-E_{u-1}\left(T_{u} \mid y_{u}\right)\right]+\sum_{u=1}^{s} \phi_{u}^{e}
\end{aligned}
$$

\footnotetext{
${ }^{16}$ In reality, households file their tax returns in the early part of the year following the tax year in question. However, as long as such filing has the potential to affect their behavior in the year of filing, the exact timing of the filing is less important. We assume it happens at the end of period $t$ for a simplicity of notation.
} 
and variance

$$
\operatorname{Var}_{t}\left[\left(\tau_{s}, D_{s}\right)^{T}\right]=\Sigma_{t}+\sum_{u=t+1}^{s} S_{t}
$$

where $\Sigma_{u}$ is defined recursively by

$$
\Sigma_{u}=\frac{\operatorname{det}\left(\Sigma_{u-1}+S_{u}\right)}{\left(y_{u}, 1\right)\left(\Sigma_{u-1}+S_{u}\right)\left(y_{u}, 1\right)^{T}}\left[\begin{array}{cc}
1 & -y_{u} \\
-y_{u} & y_{u}^{2}
\end{array}\right], u=1, \ldots, t
$$

and

$$
\Gamma_{u} \equiv \frac{\left(\Sigma_{u-1}+S_{u}\right)\left(y_{u}, 1\right)^{T}}{\left(y_{u}, 1\right)\left(\Sigma_{u-1}+S_{u}\right)\left(y_{u}, 1\right)^{T}}, u=1, \ldots, t .
$$

Proof. See the Appendix.

Intuitively, in each time period $t$, relative to the previous time period $t-1$, the mean of beliefs over $\left(\tau_{s}, D_{s}\right)^{T}$ for $s>t$ is adjusted based on the realization of the tax liability surprise $T_{t}-E_{t-1}\left(T_{t} \mid y_{t}\right)$, with the slopes of the adjustment given by $\Gamma_{t}$. Note that the surprise is only due to unexpected changes in the tax parameters since any possible income change is conditioned out. ${ }^{17}$ The analytical form of $\Sigma_{t}$ underlines the fact that at the end of period $t, \tau_{t} y_{t}+D_{t}=T_{t}$ is known with certainty, and hence $\Sigma_{t}\left(y_{t}, 1\right)^{T}=0$.

Signs of the effects of the realized tax surprise in period $t$ on the expected value of the beliefs about the parameters of future tax schedules are given by the signs of the elements of $\Gamma_{t}$. Given the assumptions on $S_{t},\left(y_{t}, 1\right)\left(\Sigma_{t-1}+S_{t}\right)\left(y_{t}, 1\right)^{T}$ is positive, and hence the signs of the elements $\Gamma_{t}$ depend upon the signs of the elements of $\left(\Sigma_{t-1}+S_{t}\right)\left(y_{t}, 1\right)^{T}$. As we mentioned earlier, one would expect that an unexpectedly high realization of tax liability would lead the household to revise its belief about both the MTR and the intercept upwards. However, this prediction hinges on the covariance between the prior beliefs about the two parameters from the previous period, as well as on the covariance in the realization,

\footnotetext{
${ }^{17}$ If one assumes that the household is only confused about the MTR, but not about the intercept, then all of the elements of $S_{t}$ and $\Sigma_{0}$ except for the element $(1,1)$ are equal to zero. In this case, Proposition 1 implies that all of the elements of $\Sigma_{t-1}$ except for the element $(1,1)$ are equal to zero, and hence $\Gamma_{t}=\left(1 / y_{t}, 0\right)^{T}$. As a result, any unexpected hike in the tax liability is reflected in an increase in the expectation of future MTRs by the magnitude of the surprise in the realized average tax rate. If coupled with the assumption that there is no intercept in the tax schedule at any time period, this case corresponds to the "schmeduling" hypothesis considered by Liebman and Zeckhauser (2004). When schmeduling, a household predicts its MTR for the current period to coincide with the average tax rate realized in the previous period.
} 
relative to the expectation, of their changes in the current period. The following proposition provides sufficient conditions for the signs of the updating effects that one would expect intuitively.

Proposition 2 Suppose that

$$
-\left[S_{t}\right]_{12}<\min \left\{y_{t}\left[S_{t}\right]_{11}, \frac{\left[S_{t}\right]_{22}}{y_{t}}\right\} .
$$

Then there exists an $\varepsilon_{t}>0$ such that if $\left|\Delta y_{t}\right|<\varepsilon_{t}$, then $\left[\Gamma_{t}\right]_{11},\left[\Gamma_{t}\right]_{21}>0$. That is, an unexpected positive shock in the realized tax liability increases the mean of the belief about both $\tau_{t}$ and $D_{t}$.

Proof. See the Appendix.

That is, a sufficient condition for the intuitively appealing sign pattern is that the covariance in the perceived noise of predictable changes in $\tau$ and $D$ is not too negative and year-to-year taxable income changes are moderate. This applies even if the surprise comes from a change in the intercept only, without any real change in the MTR, and it may induce a negative substitution effect on labor supply. This is an important observation because the natural experiment employed in our identification strategy presented in the next section constitutes a lump-sum change in tax liability.

However, tax reforms often match signs of changes in MTR and the intercept of the tax schedule segment. The same is often true when switching among different tax brackets as well. Further, many households face significant income variation from one year to another. As a result, it is not clear that the sufficient condition is satisfied. We therefore put forward only a more general hypothesis: rational and well-informed households do not change their perception of current and future tax schedule parameters upon experiencing tax schedule or segment changes. The argument is particularly appealing for tax parameter changes that are predictable well in advance. On the other hand, boundedly rational or less wellinformed households may misinterpret realized tax liability surprises and may change their perception of future tax schedule parameters in ways that do not accord with their actual changes. 


\section{Identification Strategy}

We are interested in examining how parental labor income reacts to predictable lump-sum variation in after-tax income in the previous year. Our identification strategy is based on variation generated by the eligibility rules for the Child Tax Credit (CTC). Beginning in 1998, taxpayers with a dependent below 17 years of age on December 31 of the tax year in question could claim a credit of $\$ 400$ per eligible child. This credit was generally nonrefundable and only households with a sufficiently high tax liability were able to take a full advantage of the credit. ${ }^{18}$ At the same time, the Additional Child Tax Credit (ACTC) was introduced. This credit provided for limited refundability of the non-refundable part of the CTC for families with three or more qualifying children. ${ }^{19}$ The CTC was increased to $\$ 500$ for the 1999 and 2000 tax years, $\$ 600$ for the 2001 and 2002 tax years, and $\$ 1,000$ for the 2003 tax year, where it currently stands. At the same time, beginning in 2001, the ACTC was expanded to allow any family to claim the non-refundable part of the CTC up to one tenth of the excess of their earned income over $\$ 10,000 .{ }^{20}$ The CTC has historically been phased out with adjusted gross income above $\$ 110,000$ for married couples filing a joint tax return ${ }^{21}$ at the rate of 5 percent. ${ }^{22}$ In this study, we restrict attention only to married couples and assume that they file a joint tax return. ${ }^{23}$

Three features of the CTC make it a good natural experiment for testing our hypothesis of interest. First, to be eligible, the dependent child must not have reached 17 years of age

\footnotetext{
${ }^{18}$ There are several provisions in the tax code that make the tax schedule a function of whether a dependent child did or did not reach a certain age in a given tax year. One such provision is the loss of the eligibility for the personal exemption and the Earned Income Tax Credit for a dependent child who turns 19 (or 24, if a full time student). This provision has been exploited by Looney and Singhal (2006) and Dokko (2007) in order to estimate the effect of marginal tax rates on labor supply.

${ }^{19}$ These families could claim the non-refundable part of the CTC up to the amount of employee contributed social security and medicare taxes, less any earned income tax credit they received.

${ }^{20}$ The $\$ 10,000$ threshold has been indexed to inflation over time. In addition, starting in 2004, the ACTC limit was increased to 15 percent of earned income in excess of the threshold. Families with three or more eligible children could still claim the non-refundable part of the CTC up to the amount of employee contributed social security and medicare taxes less any earned income tax credit they received, if this limit turned out to be higher.

${ }^{21}$ The thresholds are $\$ 75,000$ and $\$ 55,000$ for single/head of household taxpayers and married taxpayers filing separately, respectively. None of these thresholds are indexed for inflation.

${ }^{22}$ That is, a household loses $\$ 0.05$ of the credit for every extra dollar of adjusted gross income above the threshold.

${ }^{23}$ In general, based on IRS statistics, over $95 \%$ of married households file jointly.
} 
by December 31 of the tax year in question. Because the timing of a child's 17th birthday is perfectly predictable, so is the implied timing of the net income loss. Second, due to the ACTC, virtually any household with up to two dependents and labor income between $\$ 30,000$ and $\$ 110,000$ could take advantage of the full amount of the CTC within the time period we consider (2001-2007). As a result, the loss of the CTC constitutes a pure lumpsum change in both tax liability and after-tax income. Third, it is difficult to plan the timing of birth for a particular quarter, month, or day. As a result, among families whose children turn 17 before the end of year $t$ or at the beginning of year $t+1$, eligibility for the CTC is virtually exogenous. ${ }^{24}$ Overall, losing the CTC generates an exogenous, predictable and lump-sum variation in net income. As a result, we can identify the effect of predictable lump-sum variation in tax liability in year $t$ on the growth rate of parental labor income between years $t$ and $t+1$ by comparing this growth rate for households in which a child turns 17 in a fixed time window at the end of year $t$ (the treatment group) to households in which a child turns 17 in the time window of the same length at the beginning of year $t+1$ (the control group). We can also identify an analogous effect on the level of parental labor income in year $t+1$.

The null hypothesis is that households are fully rational and fully informed, meaning that they do not misperceive the tax schedule that they face, either ex ante or ex post. Because the change is lump-sum and predictable, there is no resulting income or substitution effect. However, such a net income loss may tighten liquidity constraints. As a result, we should observe a non-negative impact on parental labor income in the subsequent year, i.e., a non-negative difference in this variable between the treatment and the control groups. The first alternative hypothesis is that households experience ex ante but not ex post misperceptions. In this case there is a non-negative income effect (assuming that leisure is a normal good). Combined with a possible tightening of liquidity constraints, this hypothesis also implies a non-negative impact on parental labor income in the subsequent year. The second alternative hypothesis is that households experience both ex ante and ex post

\footnotetext{
${ }^{24}$ In section 6, we discuss evidence why this may not be the case and test the robustness of our results to the potential endogeneity in the timing of birth.
} 
misperceptions. In this case there are non-negative income and liquidity constraint effects, but there may also be a negative substitution effect if households interpret the unexpected increase in tax liability as an increase in the MTR. As a result, the net effect on parental income in the subsequent year is ambiguous. It then follows that the finding of a zero or a positive treatment effect is consistent with all three hypotheses, whereas the finding of a negative treatment effect is only consistent with the second alternative hypothesis.

\section{Data and Empirical Implementation}

Our identification strategy requires a dataset that contains information on household labor and non-labor income, number of children and their dates of birth, as well as basic household demographic characteristics. We use two sources of data in this study. Baseline results come from the 1996-1999 and 2001-2003 waves of the U.S. Census Bureau Survey of Income and Program Participation (SIPP). The SIPP is a nationally representative longitudinal survey of households in which each household is interviewed every four months over the course of three years for a total of nine waves. This survey collects information on income, employment, and detailed demographic information on all family members. The SIPP data also contains very specific information on the year and month of birth of each child in a household. Based on this data, we compute tax liabilities and tax rates using the NBER's TAXSIM (Feenberg and Coutts, 1993) calculator. An advantage of this dataset is its panel structure, which allows controlling for heterogeneity in the level of household labor income using fixed effects and focusing on the (presumably less noisy) growth rate of this income as the outcome variable. A disadvantage of this dataset is its relatively small size. In particular, after reducing the data to the set of suitable households, we are left with only a few hundred observations in each specification. Given that the average potential impact of misperceptions about the MTR on the growth rate of labor income may be small, this sample may not provide enough identification power to distinguish among the various hypotheses.

To address this potential problem and to examine the sensitivity of results to the usage 
of a particular dataset, we also use the Census' Integrated Public Use Microdata Series American Community Survey (ACS) from 2005-2007. ${ }^{25}$. ACS is a collection of repeated cross-sections, each including over a million households. Like SIPP, it records detailed demographic information on all family members. However, unlike SIPP, it records the quarter, as opposed to the month, of birth of household members and their age as of their last birthday. Even after reducing the data to the set of suitable households, we are typically left with around 14,000 observations in each specification. This large number of observations is the main advantage of the ACS dataset. However, this comes at a price of three disadvantages. First, given that this dataset is a series of cross-sections rather than a panel, we are not able to eliminate unobserved heterogeneity in the level of household labor income as we can with the SIPP data. Second, for the same reason, we are also unable to restrict the sample by a base-year income to a range in which the CTC loss has no impact on the MTR, since this income is potentially affected by the treatment, raising endogenous sample selection issues. Therefore we use all available data in the estimation, although the results are robust to applying the sample restriction. Third, because we only observe age as of the last birthday, as opposed to observing the year and month of birth, the classification into treatment and control groups suffers from a degree of imprecision discussed below. ${ }^{26}$ Due to these limitations, the ACS-based results should be interpreted purely as robustness tests of the SIPP-based results.

\subsection{SIPP Data}

To implement our identification strategy using the SIPP data, we require at least two complete consecutive years of data for each household in the sample. The responses of

\footnotetext{
${ }^{25}$ Unfortunately, we could not use data from the same period as in SIPP dataset because a crucial quarter-of-birth variable is not available in the ACS data during 1990-2004

${ }^{26}$ A potential disadvantage of both the SIPP and the ACS data is that we only have survey as opposed to administrative measures of household labor income. An alternative dataset with more precise information on income and tax variables would be the IRS Statistics of Income (SOI) Tax Return Microfiles. However, this dataset is unsuitable for our analysis because it does not provide explicit information on dependents' ages (and it provides only very coarse information on household demographics). In case a panel of tax returns were available, we could potentially obtain necessary information from tracking eligibility for childrelated credits and exemptions over time. However, the last year in which panel data is publicly available is 1990, which is well before the introduction of the Child Tax Credit, the main identification instrument of our study.
} 
households interviewed in each wave refer to the previous four months. Because there is no interview in 2004, data is missing for the final four months of 2003 . In order to be able to use the 2003 data on an annual basis, we compute the 2003 annual income as 12/8 times the sum of income in the first eight months of 2003. ${ }^{27}$ The coverage of the 1996-1999 panel, on which some of the robustness tests are based, starts midway through 1996 and ends midway through 1999. As a result, we use only years 1997 and 1998, which give us complete information on income.

The treated group consists of households that have at least one child who turned 17 in the last $k$ months of year $t$ and the control group consists of households that have at least one child who turned 17 in the first $k$ months of year $t+1 .{ }^{28}$ We define a "cohort" as the year in which the eligible dependent turned 17. Then, given the data availability, our baseline results, based on the 2001-2003 panel, use cohorts $t=2001$ and $t=2002$, while the robustness tests based on the 1997-1998 panel use the cohort $t=1997$.

The choice of the time window is driven by a tradeoff between the sharpness of the regression discontinuity design and the identification power due to available number of observations. In order to minimize any omitted variable bias, it is desirable to define the time window so that it is as narrow as possible. However, we have, on average, only about 35 observations per month in each of the two groups. As a result, our baseline results are based on a larger time window of $+/-6$ months. In order to evaluate the sensitivity of the findings to the choice of the time window, we also conduct analogous estimations in time windows of $+/-1$ and $+/-12$ months.

The 2001-2003 panel originally contains data on 36,700 households. We apply five restrictions to this data. First, we use data only on married couples that have at least one child who turned 17 between 2001 and 2004 (some of the households are only used in

\footnotetext{
${ }^{27}$ The subsequent results are robust to excluding the 2003 data and using only data from 2001 and 2002, for which we have complete data. These results are available from the authors upon request. Note that the results are identical for any imputation procedure that assumes that the 2003 income is a multiple, fixed across all households, of the income earned in the first 8 months of 2003. This would be the case if, for example, households earn end-of-the-year bonuses proportional to their base pay.

${ }^{28}$ There are a few households where more that one child turned 17 in the relevant time window. Although this leads to a loss of multiple credits, we still indicate the treatment or control group in the same way as for households who only lose one eligible dependent.
} 
alternative specifications to our baseline results or in subsequent robustness tests). Second, we restrict attention only to households with at least two consecutive years of complete data on yearly income ${ }^{29}$ and information on the following control variables: age and the highest achieved education level (high school diploma, associate degree, or college degree) for each spouse, and the number of dependents (children under the age of 24 living at home with parents) in the household. Third, we drop any households in which at least one of the parents was above 62 years of age in 2001 (or 2002 if data does not exist for 2001), because we do not want to confound our results by retirement decisions. Fourth, we only use data on households who have adjusted gross income, as computed by TAXSIM, in the range of $\$ 30,000$ to $\$ 110,000$ in the base year (i.e., before filing the tax return on which the loss of the Child Tax Credit is realized). This is done in order to eliminate the phase-in and the phase-out ranges of the credit, in which the loss of the CTC does impact the MTR. However, this selection on base-year income may raise issues of endogenous selection in case some of the sample households had a child turn 17 in 1999 or 2000, the first two years in which it was possible to lose the credit. ${ }^{30}$ As a result, we finally drop households in which at least one child turned 17 in 1999 or 2000 to mitigate this problem.

These restrictions significantly reduce the universe of the remaining data. Depending on the specification, our sample sizes range from as small as 57 observations in the one-month sample to as large as 883 in the 12-month sample. Moreover, a number of robustness tests contain other distinct subsamples of the data, generally around 500 observations. Panel A of Table 1 presents the means of the demographic control variables and labor income for the treatment and the control groups for the baseline six-month subsample. Results of standard t-tests show that the equality of means of control variables between these two groups cannot be rejected at any conventional level of significance for any of the variables. As a result, if there is a difference in the growth rate of labor income between the two groups, it does not appear to be driven by heterogeneity in observable demographic characteristics.

\footnotetext{
${ }^{29}$ As mentioned earlier, we impute income in the last four months of 2003 in case the information for the other 8 months of that year is available.

${ }^{30}$ Recall that the Child Tax Credit first applied in 1998. Therefore, the first year in which a household could lose it was 1999 .
} 
Using analogous sample restrictions on the 1997-1998 panel, the sample is reduced to 192 unique households (the complete 1996-1999 panel originally contained 40,188 households). Panel B of Table 1 provides summary statistics for this dataset with the treatment and control group definition based on the six-month time window (104 observations). Again, the equality of means of control variables between the two groups cannot be rejected at any conventional level of significance for any of the variables.

With observations selected as discussed, we estimate the following equation by OLS, clustering the standard errors at the household level:

$$
\Delta \ln Y_{i t+1}=\beta_{0}+\beta_{1} T_{i t}+\gamma I_{2002}+\pi^{\prime} X_{i t+1}+u_{i t+1},
$$

In this equation, $t \in\{2001,2002\}, T_{i t}$ is the indicator of the treatment group, i.e., a household with a child who turned 17 in the last $k$ months of year $t, I_{2002}$ is an indicator for $t=2002$, and $X_{i t+1}$ is a vector of household demographic characteristics in year $t+1$. The intercept and the indicator variable for $t=2002$ control for a secular non-linear time trend in labor income. As discussed before, we use time windows of $k \in\{1,6,12\}$.

\subsection{ACS Data}

In this dataset, the treated group would ideally consist of households with at least one child who turned 17 in the last quarter of year $t$, and the control group would ideally consist of households with at least one child who turned 17 in the first quarter of year $t+1$. $^{31}$ We define a "cohort" to be the year in which eligible dependents in the treatment group turned 17. Given the data availability, we use cohorts $t=2004, t=2005$ and $t=2006$.

A difficulty with the ACS dataset arises because while we know the quarter of birth of the dependent and his/her age as of the last birthday, we cannot determine when the household was interviewed. ${ }^{32}$ This means that we may potentially misclassify households

\footnotetext{
${ }^{31} \mathrm{As}$ in with the SIPP data, if more that one child turned 17 in the relevant time window, we indicate the treatment or control groups in the same way as for households that only lose one eligible dependent.

${ }^{32}$ This information is held confidential and is not released to the general public, despite our repeated requests.
} 
in our treatment and control groups. In particular, focusing on the 2005 cohort, we classify as belonging to the treatment group any household which, when interviewed during 2005, reports having a child born in the fourth quarter and reaching the age of 17 as of the last birthday. In case the interview took place anytime during the first three quarters of 2005 or during the fourth quarter of 2005 but before the child's birthday, the household is classified correctly. However, if the interview took place in the last quarter of 2005 after the child's birthday, the household is classified incorrectly. In particular, the latter households' children are a full year behind in age relative to our intended treatment group. An analogous problem arises for the control group, which includes households whose children turned 17 in the first quarter of 2004 as opposed to the first quarter of 2005, as intended, and hence are a full year ahead in age relative to our intended control group. If we hypothetically assume uniform distribution of births and interviews across the year, approximately one eighth of observations in both groups are misclassified. Both misclassifications may introduce biases into our estimates which are hard to quantify. The results should therefore be taken with caution and perhaps understood as another robustness test of the results based on SIPP data.

The original 2005-2007 dataset contains information on nearly 3,660,000 households. We apply five restrictions to this data, analogous to the restrictions in the SIPP sample. First, we use data on married couples living together with their children and no other family members, which have at least one child who is reported to be 17 as of his/her last birthday and is reported to have been born in the first or the fourth quarter (with some households only being used in robustness tests). Second, we use households with available data on age, educational level of parents and the number of dependents in the household. Third, we drop all households where at least one of the parents is above 62 years of age as of his/her preceding birthday. Fourth, we drop all households in states in which the school start cutoff date in 1993-1996 was later than (and including) September 30th. This is done in order to minimize the possibility that our treatment group would be one grade ahead of our control group, something that may affect labor income as children are leaving 
to college or moving out on their own. ${ }^{33}$ Fifth, we only use households where it is the first child who is turning 17 .

Applying these restrictions, we obtain approximately 7,250 observations in either the treatment or the control group across all the cohorts. Panel $\mathrm{C}$ of Table 1 contains the summary statistics. Standard t-tests do not reject the equality of means of individual control variables between the two groups at conventional levels of statistical significance. Hence, as in the SIPP data, if there is a difference in the labor income between the two groups, it appears not to be driven by differences in observable demographic characteristics.

With observations selected as discussed, we estimate the following equation by OLS with robust to heteroscedasticity standard errors :

$$
\ln Y_{i t+1}=\beta_{0}+\beta_{1} T_{i t}+\gamma_{1} I_{2006}+\gamma_{2} I_{2007}+\pi^{\prime} X_{i t+1}+u_{i t+1},
$$

In this equation, $t \in\{2004,2005,2006\}, T_{i t}$ is the indicator of the treatment group, i.e., whether a household $i$ has a child who turned 17 in the last quarter of year $t, I_{2006}$ and $I_{2007}$ are indicators for $t=2006$ and $t=2007$, respectively (corresponding to year after which the treatment group turned 17), and $X_{i t+1}$ is a vector of household demographic characteristics in year $t+1$. The intercept and the indicator variables for $t+1=2006$ and $t+1=2007$ control for a secular non-linear time trend in labor income.

The next section presents the estimates of $\beta_{1}$ based on (8) and (9). It also discusses a series of robustness checks that evaluate to what extent these estimates may be affected by potential correlation between $T_{i t}$ and $u_{i t+1}$ originating from an omitted variable bias due to a direct effect of a child aging on parental labor income and/or from a potential spurious correlation between the timing of birth and income.

\footnotetext{
${ }^{33}$ Of course, we ideally would like to know where each household lived when the child turned six years old but this is unobserved. Thus, we assume that the state in which the child lived when he/she turned 17 is the same state in which the child lived when he/she turned six.
} 


\section{Results}

\subsection{Main Result}

Table 2 reports our baseline results. Panel A presents estimates based on (8) using the SIPP data for the time window of plus or minus six months in column (1), one month in column (2), and 12 months in column (3). In column (1), the estimate of $\beta_{1}$ shows that households whose children turned 17 in the last six months of year $t$ have (approximately) a 3 percentage points lower growth rate of labor income between years $t$ and $t+1$ compared to households whose children turned 17 in the first six months of year $t+1$ (p-value of 0.059 ). We obtain a somewhat larger (in absolute value) and statistically more significant result for the 12-month window in column (3), with the growth rate differential being 3.8 percentage points ( $\mathrm{p}$-value of 0.001 ). On the other hand, the estimate for the one-month window is virtually zero (-0.009 with the p-value of 0.86$)$. We also reestimated each specification by the median regression in order to examine the robustness of the OLS estimates to outliers, with P-values computed by a nonparametric bootstrap with 1000 replications and clustering at household level. The estimates (p-values) are -0.026 (0.045) for the six-month window, 0.014 (0.860) for the one-month window, and -0.034 (0.001) for the twelve-month window.

Panel B, or column (4), of Table 2 presents an estimate based on (9) using the ACS data. The estimate of $\beta_{1}$ shows that households whose children are born in the last quarter and were 17 as of their last birthday when interviewed in year $t+1$ have a 2.5 percentage points lower level of parental labor income in year $t+1$ compared to households whose children are born in the first quarter and who were 17 as of their last birthday when interviewed in year $t+1$ ( $\mathrm{p}$-value of 0.011 ). When estimated by the median regression, the estimate (p-value) is -.019 (0.065).

The large sample size of the ACS allows us to further break down this result by spouse. The estimate (p-value) of $\beta_{1}$, where the dependent variable is the log of the husband's labor income, is $-0.003(0.820)$. The estimate where the dependent variable is the $\log$ of the wife's labor income is -0.041 (0.033). As a result, the response of parental labor income appears to be mostly driven by the wives', rather than the husbands' labor income. This is 
consistent with previous literature that has found that the labor supply of married women is more responsive to wage and marginal tax rate changes than that of prime age men (Hausman, 1985; Eissa, 1995; Blundell and MaCurdy, 1999).

These findings, with the exception of column (2), contradict the null and first alternative hypothesis and support the second alternative hypothesis, i.e., the presence of a substitution effect driven by an ex post (together with ex ante) misperception of the surprise in net after-tax income. ${ }^{34}$ On the other hand, the SIPP-based result for the one-month window in column (2) is not statistically significantly different from zero. Although the one-month specification most closely approaches the ideal identification design based on age discontinuity in CTC eligibility, it comes with the liability of consisting of only 57 observations, and hence large standard errors. This invites the question as to how the one-month estimate would look if we had more observations in that time window. The results for the other two larger time windows are suggestive in this respect. However, the larger the window, the larger are the possible unobserved differences between our treatment and control groups. In the next subsection, we test the robustness of our baseline results for several possible alternative explanations.

\subsection{Robustness Tests}

Identification of the effect of losing the CTC on parental labor income by means of estimating $\beta_{1}$ in (8) or (9) by OLS rests on two basic assumptions: (1) eligibility for the credit is not correlated with any variables which we do not control for and that may have a systematic effect on the outcome variable; and (2) there is no spurious non-tax correlation between the outcome and the treatment variable. The purpose of this subsection is to examine potential violations of these assumptions and their impact on our interpretation of the results.

First, despite the age discontinuity design, one may envision that the treatment variable $T_{i t}$ may be correlated with unobserved changes in tastes for supplying labor. This is

\footnotetext{
${ }^{34}$ Some of this effect may reflect a shift of labor supply to an untaxed informal sector rather than to leisure or household production. However, since neither of our datasets contain separate information on informal labor market earnings, we are not able to address this hypothesis.
} 
because, especially with larger time windows in SIPP data, the dependents on which the identification is based are somewhat older in the treatment group compared to the control group. Combined with the possibility that parental labor income responds to the age of their children, the estimate of $\beta_{1}$ may confound the effect of losing the CTC with a direct effect of the child's age. However, given the baseline result and its interpretation, this is an issue only if parents reduce their labor income in response to a child aging, for example, in response to children leaving home for college or to live on their own as they turn $18 .{ }^{35}$

Second, Dickert-Conlin and Chandra (1999) argue that if a child is to be born around the turn of the year, parents may have a preference to speed up the birth on the margin so that they can claim tax benefits for the ending calendar year. The authors also find that such behavior is more prevalent among higher income households, raising another potential spurious correlation problem, especially when using the ACS data. However, this problem does not pose a concern for our interpretation of the results since it implies that we tend to underestimate $\beta_{1}$ in absolute value, suggesting that the true coefficient is even more negative. As a result, we will focus on potential direct effects of child aging in the robustness analysis.

The first set of robustness tests consists of estimating the placebo effects of being born in a time window before versus after a certain threshold that does not trigger any tax consequences. If our baseline estimates are driven by a direct effect of child aging, we should be able to pick some of this effect up in the placebo estimates. Table 3 presents estimates of the impact on the growth rate of parental labor income between years $t$ and $t+1$ (in SIPP data, based on the 6-month window) and level of this income in year $t+1$ (ACS data, based on a 3-month window) of a child: (1) turning 15 in year $t$ versus year $t+1$; (2) turning 16 in year $t$ versus year $t+1$; and (3) turning 17 in the first half of year $t$ versus the second half of year $t^{36}$; (4) turning 18 in year $t$ versus year $t+1$; (5) turning 19 in year

\footnotetext{
${ }^{35} \mathrm{We}$ are not aware of any systematic evidence on the direction or size of this effect. There is some evidence, though, on the effect of a child going to college on household consumption. For example, Souleles (2000) finds that the effect is negligible.

${ }^{36}$ Due to the problems with exact 17th birthday classification in the ACS data, which becomes particularly severe with the middle-of-the-year cutoff, we perform the latter placebo test using only the SIPP data.
} 
$t$ versus year $t+1 .{ }^{37}$ With the exception of column (4), the estimated placebo coefficients are numerically close to and statistically indistinguishable from zero at conventional levels of statistical significance. In case of turning 18 (column (4)), the estimates are positive and, in case of SIPP, statistically significant at 5 percent level. Since at this age threshold it is the control rather than the treatment group that is affected by the loss of the CTC in the preceding tax year, the positive estimated coefficients corroborate the baseline results presented in Table 2 and their interpretation. ${ }^{38}$

This set of robustness tests shows that the baseline estimates presented in Table 2 do not appear to be driven by a direct effect of child aging on parental labor income as long as such aging effects are detectable at ages other than 17 and are not dependent upon the end of the year cutoff date. One may still argue, however, that there may be a direct timing of birth effect that is particular to the 17th birthday and to the end of the year cutoff. For example, if a local school district uses the December 31 or a nearby cutoff date for the 6th birthday of a child in order to let the child enroll in the first grade in the preceding fall, children in the treatment group are much more likely to be in the senior rather than the junior year of their high school compared to children in the control group. As a result, the former are more likely to start college or work in the subsequent fall, which may have a direct impact on the parental labor income. This is unlikely to be a problem for the ACSbased estimates since we restrict the sample to households living only in states where the 6th birthday cutoff date for first-grade enrollment is before September 30. However, given that we use 6- and 12-month windows in case of SIPP data, and an analogous restriction would severely reduce the sample size, this may be a concern for the SIPP-based estimates.

Presumably, though, a direct timing of birth effect that is particular to the 17th birthday

\footnotetext{
${ }^{37}$ To abstract from the loss of the dependent tax exemption for non-students at the age of 19, the results in column (5) are based only on households in which the 19-year-old dependent is a full-time student (in which case the household is still eligible for the exemption). Because we do not have sufficiently detailed information on student status in the SIPP data, we conduct this estimation only using the ACS data.

${ }^{38}$ Note that this result cannot be explained by the loss in the dependent tax exemption for non-students in the year the dependent turned 19, if not a full-time student, that affects the treatment group in this case. This is because if households are rational and well-informed, such loss is fully expected and hence has no income effect, although it does result in an increase in taxable income and hence potentially an increase in MTR. If the latter is the case, it should reduce labor income by the substitution effect and so we should not observe a positive estimate.
} 
should be present regardless of the presence of the CTC. As a result, this identification problem in the SIPP data can be addressed by estimating a placebo effect of a child turning 17 before or after the end of a year in the absence of the CTC and compare it with an analogous effect in the presence of the CTC. We can implement this idea by applying our estimation strategy to the time period before 1998 (when the CTC was introduced), and comparing the estimate with the 2001-2003 estimate. To do this, we apply the same estimating procedure to the 1997-1998 panel and compare the growth rate of labor income between 1997 and 1998 for households whose child turned 17 at the end of 1997 versus at the beginning of $1998 .{ }^{39}$ Panel A of Table 4 reports estimates of the pre-CTC "treatment" effect based on time windows of six and twelve months. The estimated coefficients ( $\mathrm{p}-$ values) displayed in columns (1) and (2), are 0.009 (0.607) for the six-month window and 0.001 (0.892) for the 12-month window. These estimates are an order of magnitude smaller than the ones in the baseline specifications, and statistically highly insignificant. Panel $\mathrm{B}$ of this table then compares the pre-CTC and the post-CTC treatment effects using a triple-difference estimator. Specifically, we estimate

$$
\Delta \ln Y_{i t+1}=\beta_{0}+\beta_{1} T_{i t}+\beta_{2} T_{i t} I_{\{t \geq 2001\}}+\gamma_{1} I_{\{t \geq 2001\}}+\pi^{\prime} X_{i t+1}+u_{i t+1},
$$

where $t \in\{1997,2001,2002\}$ and $I_{\{t \geq 2001\}}$ is an indicator for years after the introduction of the CTC. As before, $T_{i t}$ is an indicator for a household with a child turning 17 in the last $k$ months of year $t$ and the set of observations used to estimate this equation is restricted to only households in which at least one child turned 17 either in the last $k$ months of year $t$, or in the first $k$ months of year $t+1$, with $k \in\{6,12\}$. We add an indicator for 2001-2002 (the time period after the introduction of the CTC) to control for a secular time trend in labor income. Recall that in 1997, the households were not affected by the CTC, so $\beta_{1}$ measures the direct effect of a child turning 17 at the end of year $t$ as opposed to at the beginning of year $t+1$. On the other hand, $\beta_{2}$ measures how this effect changes between the pre-CTC period $(t=1997)$ and the post-CTC period $(t \in\{2001,2002\})$. As a result,

\footnotetext{
${ }^{39}$ Note that the introduction of the CTC in 1998 is not an issue because neither the treatment nor the control group children would have been eligible for it.
} 
the effect measured by $\beta_{2}$ can be attributed to the introduction of the CTC, assuming that all other omitted factors that affected the growth rate of labor income between these two periods affected both sets of households similarly. We estimate this equation by OLS and adjust the standard errors for clustering at the household level.

The estimate of $\beta_{2}$ is -0.038 using the six-month window (column (3)) and -0.042 using the 12-month window (column (4)), with the p-values equal to 0.126 and 0.012 , respectively. In other words, the loss on the CTC is estimated to reduce the growth rate of parental labor income by 3.8 to 4.2 percentage points, but the only the latter estimate based on the 12-month sample is statistically significant at conventional levels. These estimates are similar in sign and significance to the baseline estimates, and, if anything, are slightly larger in magnitude. The estimates of the direct effect $\beta_{1}$ of a child turning 17 before the turn of the year are positive and statistically highly insignificant, suggesting in yet another way that the direct effect of the child's date of birth does not appear to drive the baseline results.

Put together, these robustness tests document that a direct effect of a child aging or timing of birth on the growth rate of parental labor income cannot account for the baseline estimates, which therefore appear to be driven by the loss of the CTC.

\section{Discussion}

\subsection{Relation to the Empirical Literature on the Permanent In- come Hypothesis}

The results presented in the previous section are related to the tests of the permanent income hypothesis $(\mathrm{PIH})$ conducted on a cross-sectional and panel data. The basic difference between this literature and our empirical application is that the former focuses on household consumption as the outcome variable, whereas we focus on household labor income, which proxies for labor supply. However, both applications share the prediction that predictable lump-sum changes in disposable income should not, barring credit constraints, 
have any effect on the behavior of the household, be it consumption or labor supply.

The existing evidence on this prediction within the PIH literature is mixed. On the one hand, there are studies that find evidence in support of the PIH (Browning and Collado, 2001; Coulibaly and Li, 2006). On the other hand, there are studies that find, contrary to the PIH, that consumption increases with positive predictable income shocks (Parker, 1999; Souleles, 1999, 2002; Stephens, 2003; Johnson et al., 2006; Shapiro and Slemrod, 2003). What can account for the variety of these findings? Hsieh (2003) sheds light on this question by documenting that Alaskan households do not increase their consumption when paid from the (oil revenue-based) Alaska Permanent Fund, but the very same households do increase their consumption in response to the annual federal income tax refund. Hsieh comments on his result as follows: "This evidence suggests that households will take anticipated income changes into account in their consumption decisions when the income changes are large, regular, and easy to predict, but will not do so when they are small and irregular." He also states: “...many tax and fiscal policy measures will probably have an effect on aggregate consumption as long as people find it difficult and costly to understand precisely how their incomes are affected by these policies."

This reasoning suggests that whether a particular predictable change in net income is incorporated into consumption plans may depend on ex ante salience of the change. Our results suggest that a similar claim applies to ex post interpretation of predictable net income changes as well. Indeed, if an imperfect ex ante understanding of the income change is driven by costs of gathering and processing information or by bounded rationality, then there is no reason to expect perfect ex post understanding either. Absence of the latter has important implications. In case of consumption, such lack of understanding may mean that a household has biased beliefs about the extent to which the shock is temporary versus permanent, with implications for the optimal consumption plan. Our interpretation suggests that even if the duration of the shock is known, a lack of knowledge about its source, except that it comes from taxes, may have implications for perception of net prices and hence decisions on margins such as labor supply, retirement saving, charitable contributions, etc. 


\subsection{Strategic Price Obfuscation}

Our work is also related to the recent literature on strategic price obfuscation in public as well as private goods markets. In particular, if taxpayers or consumers have misperceptions regarding the true marginal user price of goods due to complexity, saliency or framing issues, then designers of pricing schemes may strategically use this to their advantage. For example, Finkelstein (2009) argues that if a particular tax or levy is less salient, then the tax base is less elastic to it, as also documented by Chetty et al. (2009). This in turn implies that the optimal tax or tax rate is higher. To support her claim, Finkelstein documents that freeway toll charges are higher in places that use electronic toll debiting compared to places that collect tolls in cash. Such an argument seemingly extends to any market with a monopoly provider, be it a public or a private good. In particular, a failure to deal with the complexity of a tax system may, apart from being an outcome of a political process, also be interpreted as a strategic choice of the government if, as a result, taxpayers underestimate their MTR. Or, reflecting on the results of Blumkin et al. (2012) and Chetty et al. (2009), it may be advantageous to tax consumption rather than income and, if possible, to minimize the salience of consumption taxes by developing legal and social norms under which posted prices exclude the tax.

It may seem, however, that such price obfuscation will not survive in competitive markets for private goods since competing firms will have an incentive to educate their competitors' customers via advertising. However, this is not necessarily the case. For example, Gabaix and Laibson (2006) show that in the presence of myopic consumers, firms will strategically shroud prices of add-on products such as printer cartridges in order to obfuscate the true cost of product usage. In addition, they show that in equilibrium there is a "debiasing curse" in that firms may not have incentives to educate their competitors' myopic customers because then they would not be able to win over their business once debiased. ${ }^{40}$

\footnotetext{
${ }^{40}$ Elisson (2006) provides a in-depth review of various theoretical approaches to modeling how firms strategically obfuscate prices.
} 


\subsection{Alternative Time Aggregation of Income}

In theory, the effect of MTR misperception should kick in as soon as a taxpayer files his income tax return for the previous year, hence usually as early as May of the year following the year in which the CTC is lost. For this reason, we went back to SIPP and obtained monthly data on income (with month being the lowest time-level of aggregation in the survey). We rerun our specifications, paying attention to the time path of income during the years $t$ and $t+1$. However, monthly data proved to be too noisy, with large standard errors making it impossible to estimate $/$ beta $_{1}$ precisely. We then attempted to conduct the analysis at a quarterly level, but again, the standard errors proved to be too large. We speculate that due to seasonality patterns in labor compensation that may differ from one industry to another and one job category to another, there is too much variation in the data relative to the likely size of the treatment effect.

\section{Conclusion}

Due to the complexity of the income tax system, taxpayers may have difficulties recognizing their true marginal tax rate. As a result, they may turn to rules of thumb in approximating how much of an additional dollar of income is taken away in taxes. We present a formal model in which households have only a limited understanding of the tax schedule they face and update their estimate of the current year's marginal tax rate based on the previous year's unexpected innovation in the realized tax liability. This in general leads to ex post tax schedule misperceptions, particularly misperceptions about the MTR. Under the assumption that taxpayers react to perceived after-tax incentives as predicted by economic theory, we examine the validity of the misperception hypothesis by measuring taxpayer labor income responses to an exogenous, lump-sum and predictable variation in the tax liability due to losing eligibility for the Child Tax Credit when the child turns 17. A fully rational and fully informed taxpayer should not react to such change. On the other hand, an imperfectly informed or a boundedly rational taxpayer may mistakenly believe that an increase in the household's tax bill reflects a higher MTR, resulting in a possible reduction 
of labor supply and labor income due to the conventional substitution effect. This CTCinduced variation in the tax liability therefore allows us to examine whether and to what extent taxpayers may not be fully informed or fully rational.

We find that households who lose the credit due to their child turning 17 at the end of a calendar year have a lower growth rate and level of parental labor income in the subsequent year compared to households whose child turns 17 at the beginning of the following calendar year. This finding is robust to a variety of tests that include placebo effects at various other age and calendar cutoffs, a placebo effect based on pre-CTC data, and a triple-difference estimator that compares the effect of a child turning 17 around the end of the year before and after the CTC was introduced. We interpret this finding as evidence for the presence of the substitution effect on labor supply and evidence for imperfect ex post understanding of the CTC loss. Taken at face value, this result suggests that tax policy changes that are not well-understood or predicted by the affected population, despite being predictable, may have unintended behavioral and welfare consequences. In particular, changes that affect the level but not the slope of the tax schedule may result in a substitution effect that is unintended, hence increasing or reducing the deadweight loss relative to the full information case. On the other hand, changes that mostly affect the marginal tax rate may be partly interpreted as changes in the level of the tax schedule, with analogous implications for the deadweight loss. Complexity of the tax system may therefore interact with tax changes to create departures from conventionally understood welfare effects. This reasoning suggests that whenever households are likely to overestimate their MTR, providing more and better information may be beneficial. On the other hand, just the opposite is the case when households are likely to underestimate their MTR.

The simple theoretical model presented in this paper leaves several open areas for future research. First, if households face a tax schedule about which they have imperfect knowledge, they may in principle experiment in order to obtain more information. That is, there may be a feedback effect from the choice of labor income to the process of the evolution of beliefs over time. Second, as mentioned before, it is likely that the error variance in predicting changes in the tax schedule is determined endogenously by conscious 
information-gathering actions. For example, this variance can be reduced by investing time to learn about the tax code or hiring a tax advisor. Furthermore, more empirical work based on alternative sources of tax schedule variation is needed in order to refine our understanding of when and under what circumstances taxpayers are likely to experience particular misperceptions of their tax schedule. 


\section{References}

Auten, G. and R. Carroll, "The Effect of Income Taxes on Household Income," Review of Economics and Statistics, 1999, 81 (4), 681-693.

Blumkin, T., Y. Ganun, and B. J. Ruffle, "Are Income and Consumption Taxes Ever Really Equivalent? Evidence from a Real-Effort Experiment with Real Goods," 2012.

Blundell, R. and T. MaCurdy, "Labor Supply: a Review of Alternative Approaches," in O. Ashenfelter, R. Layard, and D. Card, eds., Handbook of Labor Economics, Vol. 3, Elsevier, 1999, chapter 27, pp. 1559-1695.

Brown, C. V., "Misconceptions About Income Tax and Incentives," Scottish Journal of Political Economy, 1968, 15 (1), 1-21.

Browning, M. and M. D. Collado, "The Response of Expenditures to Anticipated Income Changes: Panel Data Estimates," American Economic Review, 2001, 91 (3), $681-692$.

Buiter, W. H., "Macroeconomics of Pangloss - Critical Survey of the New Classical Macroeconomics," Economic Journal, 1980, 90 (357), 34-50.

Chetty, R., A. Looney, and K. Kroft, "Salience and Taxation: Theory and Evidence," American Economic Review, 2009, 99 (4), 1145-1177.

Choi, J., D. Laibson, and B. Madrian, "Why Does the Law of One Price Fail? An Experiment on Index Mutual Funds," Yale ICF Working Paper No. 08-14 April 2008.

Coulibaly, B. and G. Li, "Do Homeowners Increase Consumption After the Last Mortgage Payment? An Alternative Test of the Permanent Income Hypothesis," Review of Economics and Statistics, 2006, 88 (1), 10-19.

de Bartolome, C. A. M., "Which Tax Rate Do People Use - Average or Marginal," Journal of Public Economics, 1995, 56 (1), 79-96.

DeGroot, M., Optimal Statistical Decisions, McGraw-Hill, 1970.

Demery, D. and N. W. Duck, "The Theory of Rational Expectations and the Interpretation of Macroeconomic Data," Journal of Macroeconomics, 2007, 29 (1), 1-18. 
Dickert-Conlin, S. and A. Chandra, "Taxes and the Timing of Births," Journal of Political Economy, 1999, 107 (1), 161-177.

Dokko, J., "The Effect of Taxation on Lifecycle Labor Supply: Results from a Quasi-Experiment," FED Working Paper No. 2008-24 September 2007.

Eissa, N. and J. B. Liebman, "Labor Supply Response to the Earned Income Tax Credit," Quarterly Journal of Economics, 1996, 111 (2), 605-637.

Eissa, Nada, "Taxation and Labor Supply of Married Women: The Tax Reform Act of 1986 as a Natural Experiment," NBER Working Paper 5023, February 1995.

Elisson, G., "Bounded Rationality in Industrial Organization," in R. Blundell, W. Newey, and T. Persson, eds., Advances in Economics and Econometrics: Theory and Applications, Ninth World Congress, Vol. 2, Cambridge University Press, 2006, pp. $142-174$.

Feenberg, D. and E. Coutts, "An Introduction to the Taxsim Model," Journal of Policy Analysis and Management, 1993, 12 (1), 189-194.

Feige, E. L. and D. K. Pearce, "Economically Rational Expectations - Are Innovations in Rate of Inflation Independent of Innovations in Measures of Monetary and Fiscal Policy?," Journal of Political Economy, 1976, 84 (3), 499-522.

Feldstein, M., "The Effect of Marginal Tax Rates on Taxable Income: A Panel Study of the 1986 Tax Reform Act," Journal of Political Economy, 1995, 103 (3), 551-572.

Finkelstein, A., "E-ZTax: Tax Salience and Tax Rates," Quarterly Journal of Economics, 2009, 124 (3).

Fujii, E. T. and C. B. Hawley, "On the Accuracy of Tax Perceptions," Review of Economics and Statistics, 1988, 70 (2), 344-347.

Gabaix, X. and D. Laibson, "Shrouded Attributes, Consumer Myopia, and Information Suppression in Competitive Markets," Quarterly Journal of Economics, 2006, 121 (2), 505-540.

Goolsbee, A., "What Happens When You Tax the Rich? Evidence from Executive Compensation," Journal of Political Economy, 2000, 108 (2), 352-378.

Gruber, J. and E. Saez, "The Elasticity of Taxable Income: Evidence and 
Implications," Journal of Public Economics, 2002, 84 (1), 1-32.

Hausman, J., "Taxes and Labor Supply," in A. Auerbach and M. Feldstein, eds., Handbook of Public Economics, Vol. 1, Elsevier, 1985, chapter 4, pp. 213-263.

Hossain, T. and J. Morgan, “...Plus Shipping and Handling: Revenue (Non) Equivalence in Field Experiments on eBay," B.E. Journals in Economic Analysis and Policy: Advances in Economic Analysis and Policy, 2006, 6 (2), 1-27.

Hsieh, C. T., "Do Consumers React to Anticipated Income Changes? Evidence from the Alaska Permanent Fund," American Economic Review, 2003, 93 (1), 397-405.

Johnson, D. S., J. A. Parker, and N. S. Souleles, "Household Expenditure and the Income Tax Rebates of 2001," American Economic Review, 2006, 96 (5), 1589-1610.

Kopczuk, W., "The Optimal Elasticity of Taxable Income," Journal of Public Economics, 2005, 84 (1), 91-112.

Kotlikoff, L. and D. Rapson, "Does It Pay, at the Margin, to Work and Save? Measuring Effective Marginal Taxes on Americans' Labor Supply and Saving," in James M. Poterba, ed., Tax Policy and the Economy, Vol. 21, The MIT Press, 2007, pp. $81-143$.

Liebman, Jeffrey B. and Richard J. Zeckhauser, "Schmeduling," Manuscript, Harvard, October 2004.

Looney, Adam and Monica Singhal, "The Effect of Anticipated Tax Changes on Intertemporal Labor Supply and the Realization of Taxable Income," FED Working Paper No. 2005-44 September 2006.

Parker, J. A., "The Reaction of Household Consumption to Predictable Changes in Social Security Taxes," American Economic Review, 1999, 89 (4), 959-973.

Poterba, J. M. and A. A. Samwick, "Taxation and Household Portfolio Composition: US Evidence from the 1980s and 1990s," Journal of Public Economics, 2003, $87(1), 5-38$.

Reis, R., "Inattentive Consumers," Journal of Monetary Economics, 2006, 53 (8), $1491-1530$.

Romich, J. L. and T. Weisner, "How Families View and Use the EITC: Advance 
Payment versus Lump Sum Delivery," National Tax Journal, 2000, 53 (4), 1245-1265.

Saez, E., "Reported Incomes and Marginal Tax Rates, 1960-2000: Evidence and Policy Implications," in James M. Poterba, ed., Tax Policy and the Economy, Vol. 18, The MIT Press, 2004, pp. 117-173.

Shapiro, M. D. and J. Slemrod, "Consumer Response to Tax Rebates," American Economic Review, 2003, 93 (1), 381-396.

Souleles, N. S., "The Response of Household Consumption to Income Tax Refunds," American Economic Review, 1999, 89 (4), 947-958.

_ , "College Tuition and Household Savings and Consumption," Journal of Public Economics, 2000, 77 (2), 185-207.

_ , "Consumer Response to the Reagan Tax Cuts," Journal of Public Economics, 2002, 85 (1), 99-120.

Stephens, M., "'3rd of the Month": Do Social Security Recipients Smooth Consumption Between Checks?," American Economic Review, 2003, 93 (1), 406-422. 


\section{A Appendix}

Proof of Proposition 1. Choose an arbitrary time period $u \in\{0, \ldots, T\}$. Suppose that, based on the initial beliefs in period 0 and all the signals accumulated up until the end of period $u-1$, the household beliefs about $\left(\tau_{u-1}, D_{u-1}\right)$ are given by $N\left(\mu_{u-1}, \Sigma_{u-1}\right)$. Due to expected changes in the tax schedule, the beliefs about $\left(\tau_{u}, D_{u}\right)$ at the beginning of period $u$ are given by $N\left(\mu_{u-1}+\phi_{u}^{e}, \Sigma_{u-1}+S_{u}\right)$. Then the joint distribution of $\tau_{u}, D_{u}$, and $T_{u}$ is given by

$$
\left(\begin{array}{c}
\tau_{u} \\
D_{u} \\
T_{u}
\end{array}\right) \sim N\left\{\left(\begin{array}{c}
\mu_{u-1}+\phi_{u}^{e} \\
\left(y_{u}, 1\right)\left(\mu_{u-1}+\phi_{u}^{e}\right)
\end{array}\right),\left[\begin{array}{cc}
\Sigma_{u-1}+S_{u} & \left(\Sigma_{u-1}+S_{i}\right)\left(y_{u}, 1\right)^{T} \\
\left(y_{i u}, 1\right)\left(\Sigma_{i u-1}+S_{i}\right) & \left(y_{u}, 1\right)\left(\Sigma_{u-1}+S_{u}\right)\left(y_{u}, 1\right)^{T}
\end{array}\right]\right\}
$$

Based on observing the realization of $T_{u}$, the posterior belief about $\left(\tau_{u}, D_{u}\right)$ is then given by (DeGroot, 1970)

$$
\left(\begin{array}{c}
\tau_{u} \\
D_{u}
\end{array}\right) \sim N\left\{\mu_{u-1}+\phi_{u}^{e}+\Gamma_{u}\left[T_{u}-E_{u-1}\left(T_{u} \mid y_{u}\right)\right], \Sigma_{u}\right\}
$$

where $\Sigma_{u}$ and $\Gamma_{u}$ are given by (5) and (6). Recursive application of this formula then gives (3) for any $u \leq t$. For $u>t$, the mean and the variance of the beliefs are only affected by addition of independent increments of tax parameter changes.

Proof of Proposition 2. Note that (5) implies that $\Sigma_{t-1}\left(y_{t-1}, 1\right)^{T}=0$, and hence

$$
\begin{aligned}
\left(\Sigma_{t-1}+S_{t}\right)\left(y_{t}, 1\right)^{T} & =\Sigma_{t-1}\left(y_{t}, 1\right)^{T}+S_{t}\left(y_{t}, 1\right)^{T} \\
& =\Sigma_{t-1}\left(y_{t-1}, 1\right)^{T}+\Sigma_{t-1}\left(\Delta y_{t}, 0\right)^{T}+S_{t}\left(y_{t}, 1\right)^{T} \\
& =\Sigma_{t-1}\left(\Delta y_{t}, 0\right)^{T}+S_{t}\left(y_{t}, 1\right)^{T}
\end{aligned}
$$

Given (7), both elements of $S_{t}\left(y_{t}, 1\right)^{T}$ are strictly positive. As a result, if $\left|\Delta y_{t}\right|$ is small enough, the same sign pattern applies to the elements of $\left(\Sigma_{t-1}+S_{t}\right)\left(y_{t}, 1\right)^{T}$, and hence, by (6), also the elements of $\Gamma_{t}$. 


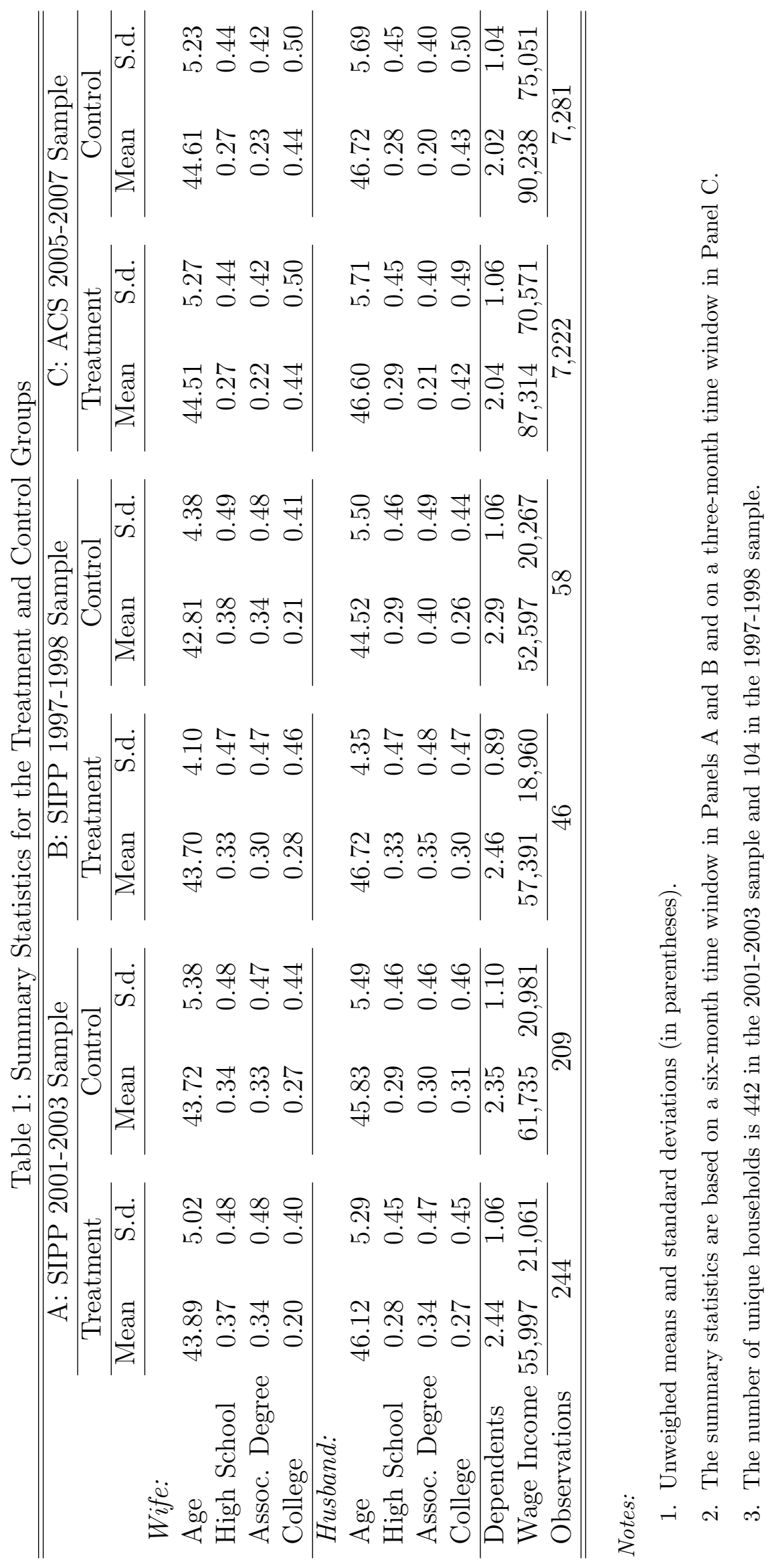


Table 2: The Effect of Losing CTC Eligibility on Parental Labor Income

\begin{tabular}{|c|c|c|c|c|}
\hline \multirow[b]{2}{*}{ Time Window +/- } & \multicolumn{3}{|c|}{ A: SIPP Sample } & \multirow{2}{*}{$\begin{array}{r}\text { B: ACS Sample } \\
3 \text { Months } \\
(4)\end{array}$} \\
\hline & $\begin{array}{r}6 \text { Months } \\
(1)\end{array}$ & $\begin{array}{r}1 \text { Month } \\
(2)\end{array}$ & $\begin{array}{r}12 \text { Months } \\
(3)\end{array}$ & \\
\hline Treatment & -0.030 & -0.009 & -0.038 & -0.030 \\
\hline & $(0.059)$ & $(0.860)$ & $(0.001)$ & $(0.021)$ \\
\hline$t=2002$ & $\begin{array}{r}-0.021 \\
(0.192)\end{array}$ & $\begin{array}{r}-0.045 \\
(0.324)\end{array}$ & $\begin{array}{r}-0.014 \\
(0.212)\end{array}$ & \\
\hline$t=2006$ & & & & $\begin{array}{r}0.020 \\
(0.195)\end{array}$ \\
\hline$t=2007$ & & & & $\begin{array}{r}0.073 \\
(0.000)\end{array}$ \\
\hline Observations & 453 & 57 & 883 & 14,503 \\
\hline Number of Households & 442 & 57 & 671 & \\
\hline R-squared & 0.031 & 0.022 & 0.023 & 0.19 \\
\hline
\end{tabular}

Notes:

1. Columns (1)-(3) present OLS estimates of (8) using the SIPP 2001-2003 sample, with $t \in$ $\{2001,2002\}$. Column (4) presents the OLS estimate of (9) using the ACS 2005-2007 sample, with $t \in\{2004,2005,2006\}$. In both cases, the additional control variables (estimates not displayed) are a constant, age and age squared of both parents, education level indicators of both parents, and the total number of dependents in the household.

2. P-values based on standard errors clustered at household level in parentheses. 
Table 3: Post-CTC Placebo Effects

\begin{tabular}{lrrrrr}
\hline \hline Event & Turning 15 & Turning 16 & Turning 17 & Turning 18 & Turning 19 \\
Time Threshold & Dec. 31 & Dec. 31 & June 30 & Dec. 31 & Dec. 31 \\
& $(1)$ & $(2)$ & $(3)$ & $(4)$ & $(5)$ \\
\hline SIPP 2001-2003 & 0.006 & -0.009 & -0.019 & 0.045 & \\
& $(0.705)$ & $(0.614)$ & $(0.186)$ & $(0.025)$ & \\
Observations & 515 & 483 & 471 & 529 & \\
\hline ACS 2005-2007 & 0.017 & -0.013 & & 0.020 & 0.007 \\
& $(0.227)$ & $(0.315)$ & & $(0.141)$ & $(0.714)$ \\
Observations & 12,201 & 13,630 & & 11,959 & 5,979 \\
\hline \hline
\end{tabular}

Notes:

1. The SIPP row presents OLS estimates of $\beta_{1}$ in (8) with $t \in\{2001,2002\}$ based on a time window of $+/-6$ months. The ACS row presents the OLS estimates of $\beta_{1}$ in (9) with $t \in$ $\{2004,2005,2006\}$ based on a time window of $+/-3$ months. $T_{i t}$ is defined as an indicator for an event defined in the heading of the table. In all specifications, the additional control variables (estimates not displayed) are constant, binary indicators for year, age and age squared of both parents, education level indicators of both parents, and the total number of dependents in the household.

2. The estimate in column (5) is based only on households where the 19-year-old dependent is a college student.

3. P-values based on robust standard errors clustered at the household level (where relevant) in parentheses. 
Table 4: Pre-CTC Placebo Effects and Triple Difference Estimates

\begin{tabular}{|c|c|c|c|c|}
\hline \multirow[b]{2}{*}{ Event } & \multicolumn{2}{|c|}{ A: Pre-CTC Placebo Effects } & \multicolumn{2}{|c|}{ B: Triple Difference } \\
\hline & Turning 17 & Turning 17 & Turning 17 & Turning 17 \\
\hline \multirow[t]{2}{*}{ Time Window +/- } & 6 Months & 12 Months & 6 Months & 12 Months \\
\hline & (1) & $(2)$ & (3) & (4) \\
\hline \multirow[t]{2}{*}{ Treatment $_{i t}$} & 0.009 & 0.002 & 0.009 & 0.005 \\
\hline & $(0.607)$ & $(0.844)$ & $(0.645)$ & $(0.650)$ \\
\hline \multirow[t]{2}{*}{ Treatment $_{i t} \times(t \geq 2001)$} & & & -0.038 & -0.042 \\
\hline & & & $(0.126)$ & $(0.012)$ \\
\hline \multirow[t]{2}{*}{$(t \geq 2001)$} & & & 0.027 & 0.023 \\
\hline & & & $(0.027)$ & $(0.078)$ \\
\hline Observations & 104 & 196 & 557 & 1,079 \\
\hline Number of Households & 104 & 196 & 546 & 867 \\
\hline R-squared & 0.093 & 0.034 & 0.022 & 0.019 \\
\hline
\end{tabular}

Notes:

1. Columns (1) and (2) present OLS estimates of (8) with $t=1997$. Specifications (3) and (4) present OLS estimates of (10), with $t \in\{1997,2001,2002\}$. In all specifications, the additional control variables are (estimates not displayed) a constant, age and age squared of both parents, education level indicators of both parents, and the total number of dependents in the household.

2. P-values based on standard errors clustered at household level in parentheses.

3. Source: SIPP 2001-2003 and SIPP 1997-1998. 
Figure 1: Effective and Statutory MTR Schedules for Married Couples Filing Jointly in 2002

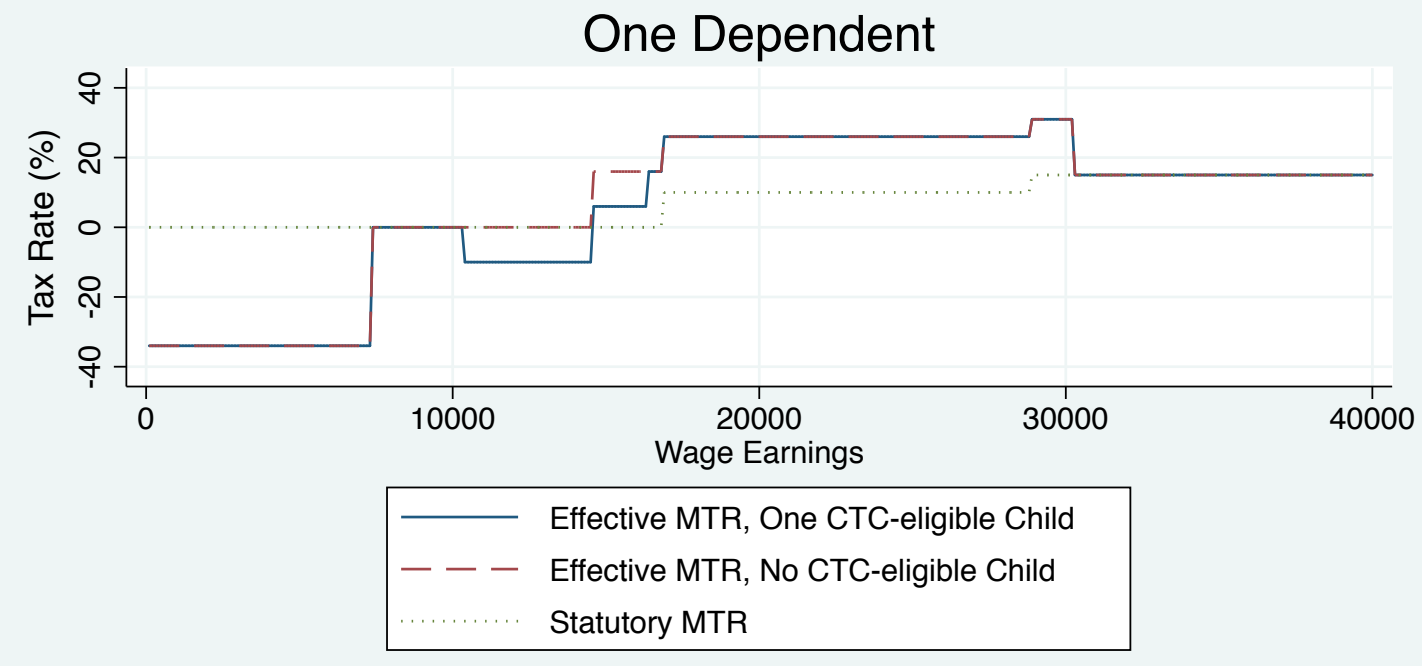

Two Dependents

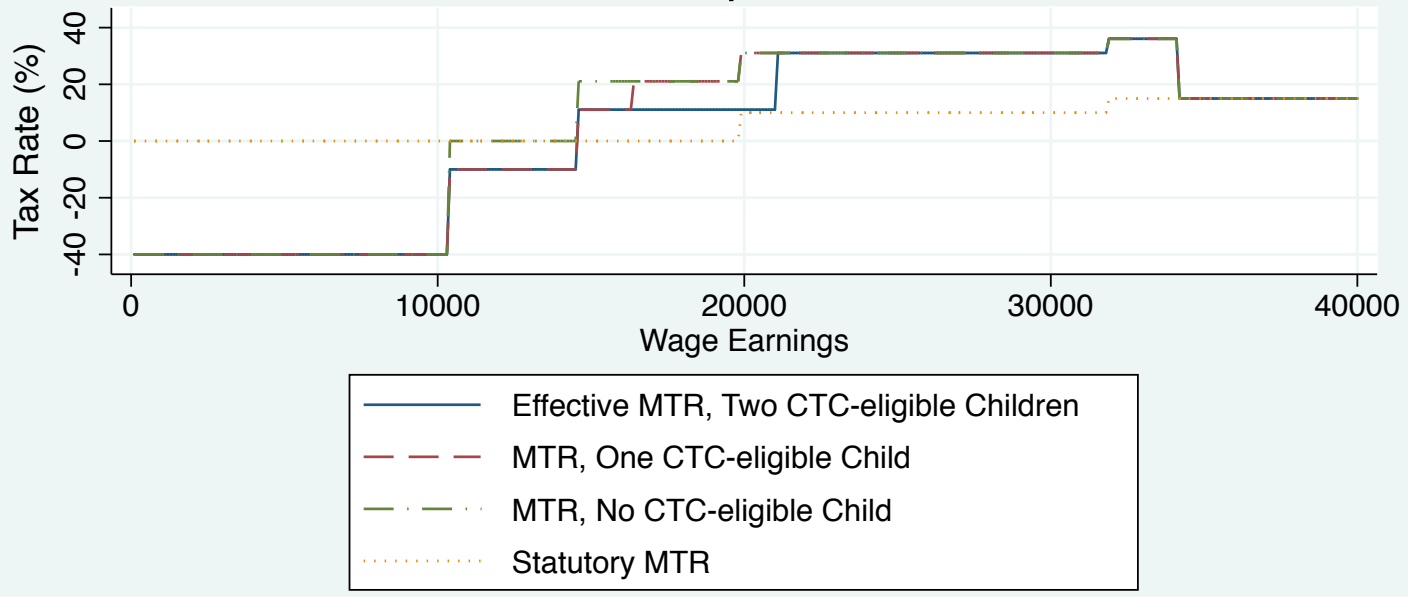

Notes:

1. The plots are based on the assumption that a household earns only labor income, does not itemize its deductions, and that all household members, including dependents, are eligible for a personal exemption.

2. Source: TAXSIM and Urban/Brookings Tax Policy Center. 


\section{Working Paper Series}

ISSN 1211-3298

Registration No. (Ministry of Culture): E 19443

Individual researchers, as well as the on-line and printed versions of the CERGE-EI Working Papers (including their dissemination) were supported from institutional support RVO 67985998 from Economics Institute of the ASCR, v. v. i.

Specific research support and/or other grants the researchers/publications benefited from are acknowledged at the beginning of the Paper.

(c) Naomi E. Feldman and Peter Katuščák, 2012

All rights reserved. No part of this publication may be reproduced, stored in a retrieval system or transmitted in any form or by any means, electronic, mechanical or photocopying, recording, or otherwise without the prior permission of the publisher.

Published by

Charles University in Prague, Center for Economic Research and Graduate Education (CERGE) and

Economics Institute ASCR, v. v. i. (EI)

CERGE-EI, Politických vězňů 7, 11121 Prague 1, tel.: +420 224005 153, Czech Republic.

Printed by CERGE-EI, Prague

Subscription: CERGE-EI homepage: http://www.cerge-ei.cz

Phone: + 420224005153

Email: office@cerge-ei.cz

Web: http://www.cerge-ei.cz

Editor: Michal Kejak

The paper is available online at http://www.cerge-ei.cz/publications/working_papers/.

ISBN 978-80-7343-257-7 (Univerzita Karlova. Centrum pro ekonomický výzkum a doktorské studium)

ISBN 978-80-7344-249-1 (Národohospodářský ústav AV ČR, v. v. i.) 
CERGE-EI

P.O.BOX 882

Politických vězňů 7

11121 Praha 1

Czech Republic http://www.cerge-ei.cz 